\title{
Congenital Human Thyroglobulin Defect due to Low Expression of the Thyroid-specific Transcription Factor TTF-1
}

Alvaro Acebrón, Pedro Aza-Blanc, Dévora L. Rossi, Luis Lamas, ${ }^{\dagger}$ and Pilar Santisteban

Instituto de Investigaciones Biomédicas, Consejo Superior de Investigaciones Científicas, 28029 Madrid, Spain

\begin{abstract}
TTF-1 and Pax-8 are thyroid-specific transcription factors, from homeo and paired box genes, respectively, that are responsible for thyroid development and for thyroglobulin and thyroperoxidase gene expression. However, TTF-1 and Pax-8 preferentially bind to the thyroglobulin and thyroperoxidase promoters, respectively. Here, we have studied a patient with defective thyroglobulin synthesis. Thyroglobulin mRNA was found at very low levels while the mRNA for thyroperoxidase was found to be more abundant compared with control tissue. The low levels of thyroglobulin mRNA are caused by a transcriptional defect due to the virtual absence of TTF-1 expression as determined by Northern blot analysis, reverse transcriptase-PCR, and electrophoretic mobility shift assays. The level of Pax-8 mRNA was the same in the goiter and in the control thyroid. These results are the first reported evidence of a congenital goiter with a thyroglobulin synthesis defect due to the low expression of the thyroid-specific transcription factor TTF1. Moreover, these data suggest that TTF-1 and Pax-8 would be differentially regulating thyroglobulin and thyroperoxidase gene transcription. (J. Clin. Invest. 1995. 96:781-785.) Key words: congenital hypothyroidism - thyroglobulin defect - thyroid transcription factors - thyroid-specific genes - homeo and paired box genes
\end{abstract}

\section{Introduction}

Human congenital hypothyroidism is a clinical situation giving rise to abnormal growth and neurological development which is a consequence of low level production of thyroid hormones. The biosynthesis of thyroid hormones requires the normal structure of the thyroglobulin ( $\mathrm{Tg}) .{ }^{1}$ Abnormalities in the synthesis

\footnotetext{
${ }^{\dagger}$ This work is dedicated to the memory of Dr. Luis Lamas.

Alvaro Acebrón and Pedro Aza-Blanc contributed equally to this work and both should be considered first authors.

Address correspondence to Pilar Santisteban, Instituto de Investigaciones Biomédicas, Calle Arturo Duperier, 4, 28029 Madrid, Spain. Phone: 1-5854644; FAX: 1-5854587.

Received for publication 24 February 1995 and accepted in revised form 1 May 1995.
}

1. Abbreviations used in this paper: EMSA, electrophoretic mobility shift assay; RT, reverse transcription; Tg, thyroglobulin; TPO, thyroperoxidase; TSH, thyrotropin (thyroid stimulating hormone); TSH-R, TSH receptor; TTF, thyroid transcription factor.

J. Clin. Invest.

(C) The American Society for Clinical Investigation, Inc.

0021-9738/95/08/0781/05 \$2.00

Volume 96, August 1995, 781-785 of $\mathrm{Tg}$ protein, changes in $\mathrm{Tg} \mathrm{mRNA}$ and alterations in $\mathrm{Tg}$ gene, have been described as the cause of human $\mathrm{Tg}$ synthesis defects (1). Clinically, many of these patients exhibit very large goiter as a consequence of chronically increased levels of thyrotropin (TSH). Most of these abnormalities appear to be transmitted in an autosomal recessive fashion with a high prevalence of consanguinity in the affected families. Both sexes are affected and the parents are considered heterozygous and unaffected. Frequently more than one sibling is affected in one given generation.

The rat $\mathrm{Tg}$ promoter has been studied extensively (2) and three thyroid-specific transcription factors have been identified to bind to this promoter: thyroid transcription factors 1 and 2 (TTF-1 and TTF-2) $(2,3)$ and Pax-8 (4). All of them bind to the thyroperoxidase (TPO) promoter too $(4,5)$. However, TTF1 and Pax-8 preferentially bind to the Tg and TPO promoters, respectively (4). In addition TTF-1 binds to the TSH receptor (TSH-R) gene promoter $(6,7)$. The genes for TTF-1 and Pax8 have been cloned disclosing that they contain homeo (3) and paired ( 8 ) boxes, respectively. It is accepted that both are responsible for thyroid phenotype and development (9). The recent availability of this information has given us the opportunity to demonstrate here, for the first time, that the cause of a congenital goiter in a woman with almost no detectable levels of Tg mRNA was the low expression of the transcription factor TTF-1. Our data also show high levels of TPO mRNA and normal levels of Pax-8. These results, taken together, suggest that, though TTF- 1 and Pax-8 are able to bind to both Tg and TPO promoters, each transcription factor must differentially regulate each gene.

\section{Methods}

Case report. A woman with familial congenital goiter, with two brothers affected, was studied. The clinical and biological reports suggested a defective thyroglobulin synthesis. The family pedigree (Fig. 1) shows no consanguinity or history of goiter. The genetic nature (autosomic recessive) of the disease was ascertained by this finding and by the fact, according to historical reports, that two brothers had the same clinical abnormalities. Unfortunately they were not accessible for study. Information about them was collected and we know that one of the brothers was studied $20 \mathrm{yr}$ ago and diagnosed as a $\mathrm{Tg}$ synthesis defect since he presented the same clinical and laboratory data as the patient studied here. He was operated on and a total thyroidectomy was performed. The gland was studied in a different hospital and we could not recover any piece of it. The other brother had goiter from childhood.

The study of the patient reported here commenced in 1967 when she was $15 \mathrm{yr}$ of age. No detailed medical record was available before that year. Consultation at an endocrine clinic revealed the presence of a large goiter and signs of tracheal compression. The patient showed normal growth and mental development. The thyroid status parameters corresponded with those described for familial congenital goiter and were: a low serum T4 level, $2.1 \mu \mathrm{g} / 100 \mathrm{ml}$ (normal values 4-10 $\mu \mathrm{g}$ / $100 \mathrm{ml}$ ); a low serum T3 level, $0.6 \mathrm{ng} / \mathrm{ml}$ (normal values $1-2 \mathrm{ng} / \mathrm{ml}$ ); and an elevated serum TSH level, $100 \mu \mathrm{U} / \mathrm{ml}$ (normal values 2-12 


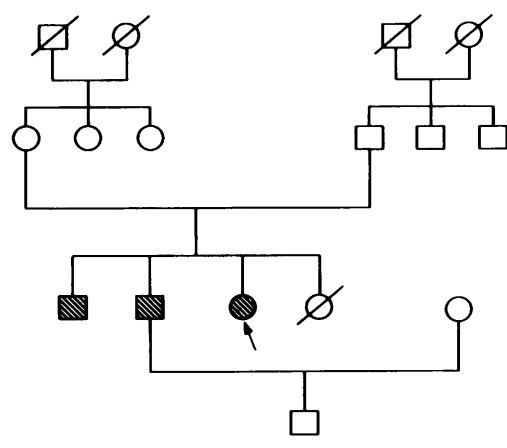

Figure 1. Pedigree of the family studied with congenital goiter. Squares represent males and circles represent females. The parents have been considered heterozygous and unaffected. The arrow indicates the patient studied in this work Two brothers are also affected.

$\mu \mathrm{U} / \mathrm{ml})$. The ${ }^{127} \mathrm{I}$ content and the protein bound iodine were low, 2.8 and $1.6 \mu \mathrm{g} / \mathrm{ml}$, respectively. Thyroidal radio iodine uptake $\left({ }^{131} \mathrm{I}\right)$ was elevated at $2 \mathrm{~h}(78 \%)$ and $24 \mathrm{~h}(94 \%)$. The perchlorate discharge test was negative. Serum $\mathrm{Tg}$ level was undetectable. At this point a hemithyroidectomy was performed, after treatment of the patient with thyroid extract. After several follow-up visits, in 1980 the patient again exhibited a high TSH level $(80.7 \mu \mathrm{g} / \mathrm{ml})$ and a low T3 level $(0.3 \mathrm{ng} /$ $\mathrm{ml}$ ). The patient received further thyroid extract treatment and in 1989 it was decided that a total thyroidectomy was necessary. The control thyroid was obtained from the normal tissue of three different human adenomas. All the pieces from the different glands were stored at $-70^{\circ} \mathrm{C}$ for both biochemical and molecular studies.

Gel filtration and electrophoresis. Thyroid tissue (controls and different parts of the goiter) was sliced and homogenized in buffer A (10 mM Tris- $\mathrm{HCl}, \mathrm{pH} 7.7$, containing $150 \mathrm{mM} \mathrm{NaCl}$ ). Subcellular fractionation was performed using sequential centrifugation. The $100,000 \mathrm{~g}$ supernatant was fractionated on a Sepharose 6B column using buffer $\mathrm{A}$ as eluent. The fractions corresponding to each peak were pooled and concentrated for subsequent SDS-PAGE (7\%).

Iodine and iodoamino acids determination. Total ${ }^{127}$ I content was measured in the homogenate, in the $\$ 100$ fraction, and in the different column peaks $(10)$. The $19 \mathrm{~S} \mathrm{Tg}$ peak was digested with pronase to determine iodothyronines and iodotyrosines after chromatographic analysis (11)

RNA isolation and Northern blot analysis. Total RNA was extracted by the guanidinium-isothiocyanate method (12). In some cases poly $(\mathrm{A})^{+}$RNA was obtained by oligo (dT)-cellulose chromatography (13). Samples of total RNA or poly (A) ${ }^{+}$RNA were electrophoresed in $1 \%$ agarose gels containing $2.2 \mathrm{M}$ formaldehyde, blotted to nylon membranes (Nytran; Schleicher and Schuell, Keene, NH), and hybridized with different probes labeled by random oligo priming (13). We have previously isolated a partial human TTF- 1 cDNA $(1,200 \mathrm{bp}$, corresponding to the $3^{\prime}$ end of the rat c-DNA [3]) from a human thyroid cDNA $\lambda$-gt11 expression library.

The Northern blots were densitometrically scanned. The data are represented as the mean \pm the standard deviation of three independent experiments performed with RNA from different parts of the goiter or the three different control glands.

Reverse transcription and polymerase chain reaction ( $R T-P C R)$. The reverse transcription reaction was performed from $5 \mu \mathrm{g}$ of total RNA in $20 \mu$ l of reaction mixture containing $2 \mu \mathrm{l}$ of $10 \times$ PCR buffer (Perkin-Elmer Cetus Corp., Norwalk, CT), 40 U RNasin (Promega, Madison, WI), $400 \mathrm{U}$ Moloney murine leukemia virus reverse transcriptase (GIBCO-BRL, Gaithersburg, MD), $400 \mu \mathrm{M}$ deoxynucleotides (dNTPs) (Pharmacia Biotech Inc., Piscataway, NJ), and $1 \mu \mathrm{g} / \mathrm{sample}$ of 6-mer oligonucleotide [ $\left.\mathrm{d}\left(\mathrm{N}_{6}\right) 5^{\prime}-\mathrm{PO}_{4}\right]$ (Pharmacia Biotech Inc.). Incubations were performed for $30 \mathrm{~min}$ at $42^{\circ} \mathrm{C}, 5 \mathrm{~min}$ at $95^{\circ} \mathrm{C}$, and 5 $\min$ at $5^{\circ} \mathrm{C}$. After cooling, half of the volume of the RT reaction was adjusted to $80 \mu \mathrm{l}$ and $2.5 \mathrm{U}$ of Taq polymerase (Perkin-Elmer Cetus Corp.), $8 \mu \mathrm{l}$ of $10 \times$ PCR buffer, and $2 \mu \mathrm{M}$ of the appropriate primer was added. The TTF-1 primers were T1 (CGCTGTCCTGCTGCAGTTACTGCTGCGCCGCC) and T2 (GCCGGAAGCGTCGGGTGCTCTTCTCCCAG). The $\beta$-actin primers were $\beta 1$ (GTGTAAAACGCA-
GCTCAGTAACAGTCCG) and $\beta 2$ (GGTATGGAATCCTGTGGCATCCATGAAA). The PCR reaction was run on a DNA thermal cycler (Perkin-Elmer Cetus Corp.) with the following conditions: denaturation at $95^{\circ} \mathrm{C}$ for $30 \mathrm{~s}$, annealing at $60^{\circ} \mathrm{C}$ for $30 \mathrm{~s}$, and extension at $72^{\circ} \mathrm{C}$ for $1 \mathrm{~min}$. For TTF- 1 and $\beta$-actin 40 and 35 cycles were used, respectively. The PCR products were electrophoresed in a $2 \%$ agarose gel, blotted onto nylon membranes, and hybridized with human TTF- 1 and rat $\beta$ actin probes.

Nuclear extract preparation and mobility shift assays. Nuclear extracts were performed as described previously (2). Protein concentration was measured with a protein assay kit (Bio Rad Laboratories, Hercules, CA) using bovine serum albumin as the standard. For electrophoretic mobility shift assays (EMSA), $5 \mu \mathrm{g}$ of nuclear proteins was incubated with $50 \mathrm{pg}$ of ${ }^{32} \mathrm{P}$-labeled double-stranded DNA oligonucleotide $\mathrm{C}(5$ 'CACTGCCCAGTCAAGTGTTCTTGA-3') or A (5'-TACTGATTACTCAAGTATTCTTAG-3') as described (2). The resulting DNA-protein complexes were separated from free DNA on a $5 \%$ polyacrylamide gel (2).

\section{Results}

Biochemical and molecular analysis defining the patient as a thyroglobulin synthesis defect. Gel filtration and SDS-PAGE revealed that almost no thyroidal $\mathrm{Tg}$ is present in the patient (Fig. 2, $a$ and $b$ ). It is important to note the conspicuous albumin peak present in the goiter that is iodinated $\left(0.74 \mu \mathrm{g}{ }^{127} \mathrm{I} / \mathrm{mg}\right.$ protein). The fractions corresponding to the $19 \mathrm{~S} \mathrm{Tg}$ of the goiter were digested with pronase and afterwards subjected to iodoamino acid analysis. Neither iodothyronines nor iodotyrosines were detected. The results reported above suggest a defect in $\mathrm{Tg}$ gene expression. To confirm this we measured Tg mRNA levels by Northern blotting of total RNA from control thyroid or goiter after hybridization with a human Tg cDNA probe (14). As shown in Fig. $2 c$, the size of the Tg mRNA was normal $(8.4 \mathrm{~kb})$ in both cases. However, very low levels of $\mathrm{Tg}$ mRNA were observed in the goiter. After quantification of the autoradiograms by densitometric scanning and correction using the levels of $\beta$-actin mRNA (15) (Fig. $2 d$ ) we observed that the levels of Tg mRNA in the goiter were 20 -fold less abundant compared with the control.

We also analyzed the levels of TPO mRNA by hybridization of Northern blots with the human TPO cDNA (16), since it has been previously described that high levels of TPO mRNA are present in this kind of familial congenital goiter (1). The results indicate that the levels of TPO mRNA in the goiter are very high (10-fold over the control) (Fig. 2, $c$ and $d$ ).

TTF-1 and Pax-8 gene expression. Since TTF-1 is the main factor regulating $\mathrm{Tg}$ transcription, we hypothesized that the low levels of $\mathrm{Tg}$ mRNA in the goiter could be due to the low expression of TTF- 1 mRNA. We first cloned a partial sequence ( $1.2 \mathrm{~kb}$ from the 3 '-end) of TTF-1 cDNA from a human thyroid expression library. The human clone obtained (hTTF-1) showed high homology with the corresponding rat clone and was subsequently used as a probe. Northern blots containing poly (A) ${ }^{+}$ RNA from the goiter and from the control thyroid were hybridized with the hTTF-1 probe (Fig. $3 a$, left). The results obtained indicated the virtual absence of TTF-1 mRNA from the goiter (Fig. $3 a$, lanes 1 and 2). The 2.4-kb TTF-1 transcript in the normal human thyroid tissue is shown in Fig. $3 a$, lanes 3-5.

Nevertheless, the high levels of TPO mRNA detected were contradictory with our hypothesis as TTF-1 also binds to the TPO promoter (5). Another transcription factor, Pax-8, has been identified. It is known to bind to the TPO promoter with 
a

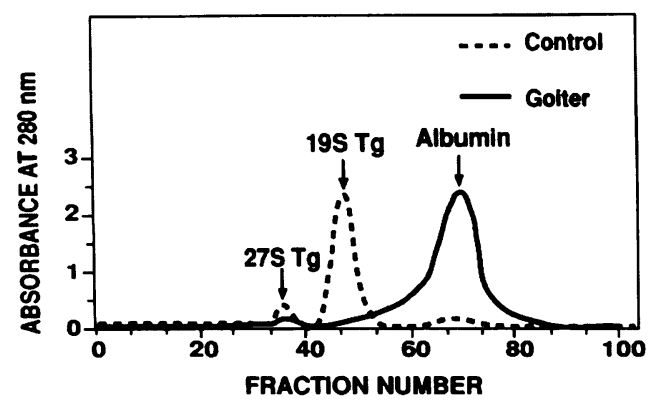

C

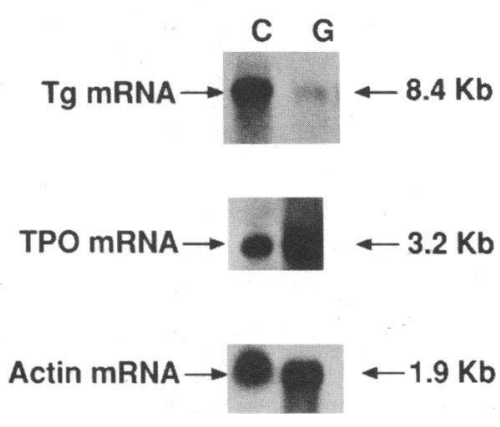

b

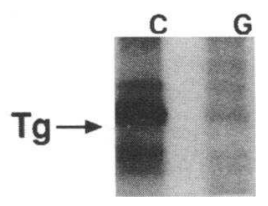

d

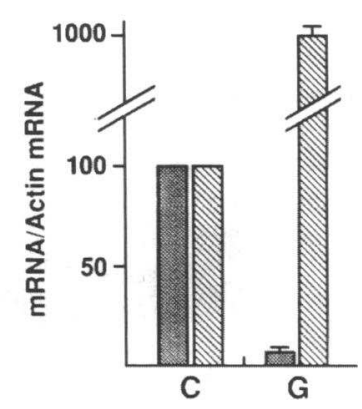

Figure 2. (a) Gel chromatography pattern of the soluble protein fraction from the congenital goiter (dashed line) and the control tissue (continuous line). Absorbance at $280 \mathrm{~nm}$ was monitored in each fraction. The elution positions of $27 \mathrm{~S}$ $\mathrm{Tg}, 19 \mathrm{~S} \mathrm{Tg}$, and albumin are indicated above each peak. The normal 19S Tg peak is absent in the goiter. However, the levels of albumin are greater compared with the control. (b) The material present in the peak corresponding to $19 \mathrm{~S} \mathrm{Tg}$ was concentrated and subjected to electrophoresis in SDS-PAGE (7\%). Tg standard and markers were run in another lane (not shown). No $\mathrm{Tg}$ protein is detected in the goiter $(G)$ after staining of the gel. $(c)$ Representative Northern blots with $30 \mu \mathrm{g}$ of total RNA from the goiter and the control glands hybridized with the corresponding hTg (top), hTPO (middle), and $\mathrm{r} \beta$ actin (bottom) probes. $(d)$ Results obtained after autoradiography and scanning densitometry of the Northern blots. In each case the mRNA levels for Tg and TPO (shaded and hatched bars, respectively) were corrected to those obtained for $\beta$-actin. The signal obtained from the control thyroid was normalized to 100 . The results are the mean $\pm S D$ of three independent experiments performed with RNA from different parts of the goiter or the three different control glands. a higher affinity than to the $\mathrm{Tg}$ promoter and overlaps one of the TTF-1 binding sites (4). Therefore the expression of this factor was determined in the goiter. Since human Pax-8 has been cloned (17) and shows a very high homology with that of rat, Northern blots containing total RNA from the goiter and the control thyroid were hybridized with the rat Pax-8 probe (4). The results obtained showed normal levels of the 3.1-kb Pax-8 mRNA in both goiter and control thyroid (Fig. $3 a$, right).

Very low levels of TTF-1 were detected by RT-PCR. Total RNA from the goiter and from the control thyroid was reverse transcribed and the corresponding DNA obtained was amplified with specific primers for TTF- 1 and $\beta$-actin. Fig. $3 b$, left, shows low levels of amplified TTF-1 in the goiter compared with the control thyroid. The levels of amplified $\beta$-actin were the same in both cases. Southern blotting and hybridization with the hTTF- 1 and $\beta$-actin probes demonstrated the specificity of the amplified products (Fig. $3 \mathrm{~b}$, middle and right). Although this is not a quantitative RT-PCR, the fact that we have used the same amount of total RNA (from goiter and control) and amplified two genes at the same time suggests that the levels of TTF-1 mRNA in the goiter are $\sim 20$-fold lower compared with the control.

Analysis of the TTF-1/DNA complex formation. By EMSA we have studied the TTF-1 protein in the goiter and its capacity to bind to its corresponding site within the $\mathrm{Tg}$ promoter. Nuclear extracts from normal human thyroid or from the goiter were

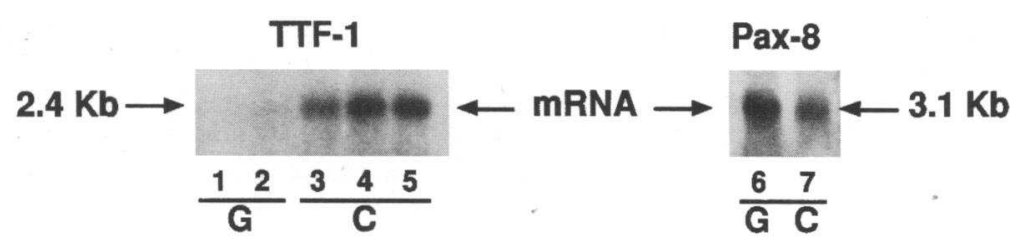

b
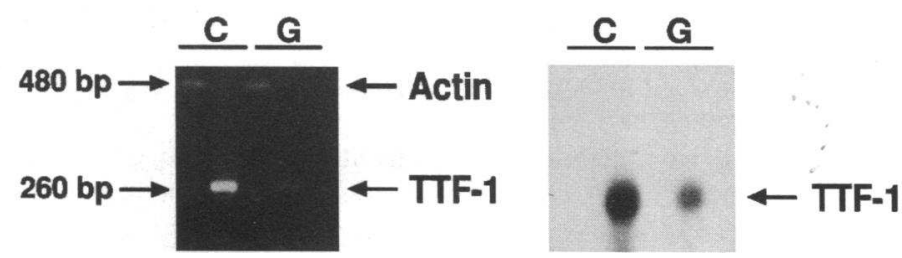
on $2 \%$ agarose gel and stained with ethidium bromide (left). The sizes of the amplified products are indicated. After Southern blotting, the PCR products were hybridized with h-TTF-1 probe (middle) or with a rat $\beta$-actin probe (right).

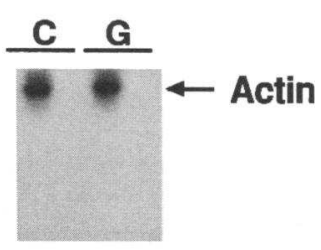

Figure 3. TTF-1 and Pax-8 gene expression. (a) 5 or $20 \mu \mathrm{g}$ of poly (A) ${ }^{+}$RNA from the goiter (lanes 1 and 2) or 2.5 or $5 \mu \mathrm{g}$ of poly (A) ${ }^{+}$RNA from the controls (lanes 3-5) was hybridized with the 3 '- end human cDNA probe for TTF-1. $30 \mu \mathrm{g}$ of total RNA from the goiter (lane 6) and from the control thyroid (lane 7) was hybridized with the full-length probe for rat Pax-8 (10). Two representative Northern blots are shown. (b) Analysis of TTF-1 gene expression by RT-PCR. Total RNA from the goiter and the control thyroid were reverse transcribed and then amplified with specific primers from TTF-1 and 

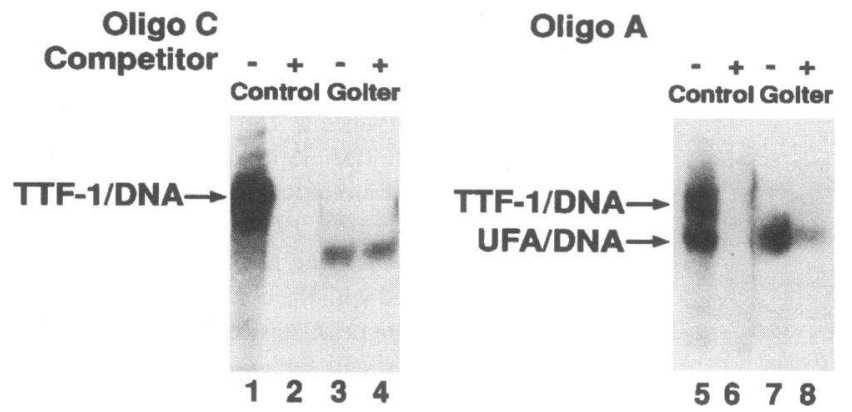

Figure 4. EMSA with nuclear extracts from the control and the goiter tissues incubated with the ${ }^{32} \mathrm{P}$-labeled $\mathrm{C}$ or $\mathrm{A}$ oligonucleotides corresponding to two different regions of the $\mathrm{Tg}$ promoter where the thyroidspecific transcription factor TTF-1 binds. An ubiquitous protein (UFA) also binds to the A region. No TTF-1/DNA complex is observed using nuclear extracts obtained from the goiter when $\mathrm{C}$ or $\mathrm{A}$ oligos were used (lanes 3 and 7). TTF-1/DNA complex is detected in the control gland (lanes 1 and 5). As shown in lane 7, although there is not a TTF-1/ DNA complex in the goiter, the presence of the UFA/DNA complex is as clear as in the control (lane 5). All the complexes are specific since their bindings are competed with a 100 -fold excess of cold oligonucleotide $\mathrm{C}$ or $\mathrm{A}$, respectively.

tested for the ability to bind to a 24-bp oligonucleotide $\mathrm{C}$ derived from one of the TTF-1 binding sites within the Tg promoter $(2,18)$. A retarded band was detected in the gel shift assay when nuclear extracts from the control thyroid were used (Fig. 4 , lane 1 ). The specificity of the complex was demonstrated by competition experiments. The TTF-1/DNA complex was competed by a 100 -fold excess of unlabeled oligonucleotide $\mathrm{C}$ (Fig. 4, lane 2). However, no retarded band corresponding to the TTF-1/DNA complex was observed when nuclear extracts prepared from the goiter were used (Fig. 4, lane 3). A protein/ DNA complex migrating below the TTF-1/DNA complex is observed in goiter nuclear extracts, but the protein of this complex is something different from TTF-1 since it was not competed by a 100 -fold excess of unlabeled oligonucleotide C (Fig. 4, lane 4). A positive control in the EMSA was used to show that the nuclear extracts from the goiter are capable of binding to another DNA element. An oligonucleotide derived from the A region of the Tg promoter was used $(2,18)$. TTF-1 and a ubiquitous protein UFA bind to this region. As shown in Fig. 4, there are two retarded bands (TTF-1/DNA and UFA/DNA complexes) when nuclear extracts from control thyroid were used (lane 5). However, only the UFA/DNA complex was found in the goiter (Fig. 4, lane 7). The complexes are specific since they were competed by an excess (100-fold) of unlabeled oligonucleotide A (Fig. 4, lanes 6 and 8). These data confirm that, even though we were able to detect very small levels of TTF-1 mRNA by RT-PCR, this small amount is not sufficient to be translated into the correspondingly active TTF-1 protein.

\section{Discussion}

The case presented in this study is in agreement with the established diagnostic criteria for congenital goiter related to impaired Tg synthesis (1). The patient had an enormous quantity of iodinated albumin and it has been suggested that iodoalbumin could play a role replacing $\mathrm{Tg}$ in thyroid hormone formation (19). In this case the low serum T3 and T4 levels found in the patient suggested that even if the albumin is iodinated it is not able to form enough thyroid hormone to prevent tissue hypothyroidism.

Despite extensive studies, the molecular basis of most of these defects remain unclear, however, it seems likely that many different mutations in the $\mathrm{Tg}$ gene are responsible for $\mathrm{Tg}$ synthesis defects (1). We have correlated the very low levels of $19 \mathrm{~S}$ $\mathrm{Tg}$ iodoprotein found in the goiter with the very low mRNA levels of the 8.4-kb Tg transcript. An explanation of the patient's condition within this study could be the presence of a mutation in the $\mathrm{Tg}$ gene. Another possible alternative would be a $\mathrm{Tg}$ gene promoter defect in TTF-1 and/or Pax-8 binding site. However, we focused our efforts in a new direction. Until now there have been no reports raising the possibility of a $\mathrm{Tg}$ gene transcription defect. This hypothesis was established as a consequence of two pieces of evidence: the almost undetectable level of $\mathrm{Tg}$ mRNA and the recent cloning of two very important thyroidspecific transcription factors TTF-1 and Pax-8 $(3,4)$. TTF-1 is the main regulator of $\mathrm{Tg}$ gene transcription. An important feature of this factor is that it is a homeoprotein. These kind of proteins play a very important role in development, cell growth, and differentiation processes (20). In the case of the rat, TTF1 has been defined as the thyroid phenotype determinant. Its appearance in the rat embryo precedes $\mathrm{Tg}$ expression by 4-5 $d(9)$. All together, this information suggested that the absence or low expression of this factor could be the cause of congenital goiters with $\mathrm{Tg}$ synthesis defect.

Nevertheless, the high levels of TPO mRNA detected were contradictory with our hypothesis and the fact that TTF-1 also binds to the TPO promoter $(5,21)$ is difficult to explain as the TTF-1 levels were very low. Another factor, Pax-8, has been recently identified. It is known to bind to the TPO promoter with a higher affinity than to the $\mathrm{Tg}$ promoter, and overlaps one of the sites for TTF-1 binding (4). Therefore, we decided to study the expression of this factor in the goiter. The results indicated normal levels of Pax-8 mRNA. At this point, the fact is that both TTF- 1 and Pax- 8 are able to bind to the Tg and TPO promoters in vitro. The situation in vivo could be different, each gene being regulated in a different manner by each factor. One possible explanation for the elevated levels of TPO mRNA could be that, in normal tissue, TTF-1 is acting like a repressor of TPO activation although it is activating Tg expression. The fact that the same transcription factor is able to activate one gene while repressing another has been described previously (22). The mechanism of this repression would be by a competition between both an inactive form of TTF- 1 and Pax-8 for the same binding site in the TPO promoter. Therefore, because of the absence of TTF-1 in the patient studied, no competition would exist, thereby leading to the constitutive activation of TPO by Pax-8.

TSH-R mRNA in the goiter was normal in size and as abundant as the control (data not shown). Since there is not reported evidence that Pax- 8 binds to the TSH-R, we cannot explain normal levels of TSH-R with the above explanation for TPO. Our explanation is that although TTF-1 binds and transcribes the TSH-R promoter (7) other factors, different from TTF-1, have been reported to control TSH-R gene expression $(23,24)$. Such factors could regulate the TSH-R in this situation.

Very low levels of TTF-1 expression were detected by RTPCR, but not sufficient to be translated into the correspondingly active TTF-1 protein, since in the EMSA we did not detect any 
TTF-1/DNA complex. This suggested once more that TTF-1 is the main cause of this $\mathrm{Tg}$ synthesis defect. We cannot rule out a possible mutation within the $\mathrm{Tg}$ promoter which would alter Tg transcription, but the fact that TTF-1 is virtually absent in the goiter should be considered enough to explain the defect. The cause of the low TTF-1 levels remains to be clarified. To accomplish this goal it will be necessary to clone the entire TTF-1 human gene. The key feature of this work is that it is the first report of a $\mathrm{Tg}$ synthesis defect due to the low levels of a thyroid-specific transcription factor. To our knowledge few other congenital defects considered to be caused by the absence or altered expression of transcription factors have been reported previously. It is known that the absence of a specific transcription factor necessary for the transcription of the HLA class II genes results in the absence of their protein products, which is characteristic of one form of congenital severe combined immunodeficiency disease (25). The causes of human congenital hypopituitarism have been reported as different mutations in the gene of the pituitary-specific transcription factor Pit-1/ GHF-1. These mutations create either a stop codon or alter the POU domain of such a factor, creating a protein unable to bind to the pituitary genes that it regulates $(26-28)$. These reports confirm, in other tissues, that the lack or altered expression of some transcription factors may lead to severe congenital defects.

\section{Acknowledgments}

We are indebted to Dr. F. Hervas and Dr. V. Pozuelo for the clinical study of the patient, to Dr. D. Jones for the critical reading of this manuscript, and to Mrs. A. Seguido for her technical assistance. The different probes were kindly provided by Dr. Di Lauro (rTTF-1 and rPax-8) (Stazione Zoologica, Naples, Italy), Dr. Vassart (hTg) (Université Libre de Bruxelles, Brussels, Belgium), Dr. Kimura (hTPO), and Dr. B. Paterson ( $r \beta$-actin) (both from the National Institutes of Health, Bethesda, MD).

This work was supported by grants DGICYT PM92-0012, CAM 182/92, FIS 92/0467 (Spain), and BIO2-CT93-0454 (CE).

\section{References}

1. Medeiros-Neto, G., H. M. Targovnik, and G. Vassart. 1993. Defective thyroglobulin synthesis and secretion causing goiter and hypothyroidism. Endocr. Rev. 14:165-183.

2. Civitareale, D., R. Lonigro, A. Sinclair, and R. Di Lauro. 1989. A thyroidspecific nuclear protein essential for tissue-specific expression of the thyroglobulin promoter. EMBO (Eur. Mol. Biol. Organ.) J. 8:2537-2542.

3. Guazzi, S., M. Price, M. De Felice, G. Damante, M. G. Mattei, and R. Di Lauro. 1990. Thyroid nuclear factor 1 (TTF-1) contains a homeodomain and displays a novel DNA binding specificity. EMBO (Eur. Mol. Biol. Organ.) J. 9:3631-3639.

4. Zannini, M., H. Francis-Lang, D. Plachov, and R. Di Lauro. 1992. Pax-8, a paired domain-containing protein binds to a sequence overlapping the recognition site of a homeodomain and activates transcription from two thyroid-specific promoters. Mol. Cell. Biol. 12:4230-4241.

5. Francis-Lang, H., M. Price, M. Polycarpou-Schwarz, and R. Di Lauro. 1992. Cell-type-specific expression of the rat thyroperoxidase promoter indicates common mechanism for thyroid-specific gene expression. Mol. Cell. Biol. 12:576588.

6. Civitareale, D., M. P. Castelli, A. Falasca, and A. Sairardi. 1993. Thyroid transcription factor 1 activates the promoter of thyrotropin receptor gene. Mol. Endocrinol. 7:1589-1595.
7. Shimura, H., F. Okajima, S. Ikuyama, Y. Shimura, S. Kimura, M. Saji, and L. D. Kohn. 1994. Thyroid-specific expression and adenosine 3', 5'-monophosphate autoregulation of the thyrotropin receptor gene involves thyroid transcription factor-1. Mol. Endocrinol. 8:1049-1069.

8. Plachov, D., K. Chowdhury, C. Walther, D. Simon, J. L. Guenet, and P. Gruss. 1990. Pax8, a murine paired box gene expressed in the developing excretory system and thyroid gland. Development (Camb.). 110:643-651.

9. Lazzaro, D., M. Price, M. De Felice, and R. Di Lauro. 1991. The transcription factor TTF-1 is expressed at onset of thyroid and lung morphogenesis and in restricted regions of the foetal brain. Development (Camb.). 113:1093-1104.

10. Benotti, J., and N. Benotti. 1963. Protein-bound iodine, total iodine and butanol-extractable iodine by partial automation. Clin. Chem. 9:404-415.

11. Lamas, L., P. Santisteban, C. Turmo, and A. M. Seguido. 1986. Evidence by in vitro enzymatic iodination of thyroglobulin that the efficiency of coupling is determined by the initial iodide concentration. Endocrinology. 118:2131-2136.

12. Chomczynski, P., and N. Sacchi. 1987. Single-step method of RNA isolation by acid guanidinium thiocyanate-phenol-chloroform extraction. Anal. Biochem. 162:156-159.

13. Sambrook, J., E. F. Fritsch, and T. Maniatis. 1989. Molecular Cloning: A Laboratory Manual. Cold Spring Harbor Laboratory, Cold Spring Harbor, NY. 7.26 .

14. Brocas, H., D. Christophe, V. Phol, and G. Vassart. 1982. Cloning of human thyroglobulin complementary DNA. FEBS (Fed. Eur. Biochem. Soc.) Lett. 137:189-192.

15. Levi, A., J. D. Eldridge, and B. M. Paterson. 1985. Molecular cloning of a gene sequence regulated by nerve growth factor. Science (Wash. DC). 229:393395.

16. Kimura, S., T. Kotani, O. W. McBride, K. Umeki, K. Hirai, T. Nakayama, and S. Othaki. 1987. Human thyroid peroxidase: complete cDNA and protein sequence, chromosome mapping, and identification of two alternately spliced mRNAs. Proc. Natl. Acad. Sci. USA. 84:5555-5559.

17. Poleev, A., H. Fickenscher, S. Mundlos, A. Winterpacht, B. Zabel, A. Eidler, P. Gruss, and D. Plachov. 1992. PAX-8, a human paired box gene: isolation and expression in developing thyroid, kidney and Wilms' tumors. Development (Camb.). 116:611-623.

18. Christophe, D., B. Cabrer, A. Bacolla, H. Targovnik, V. Pohl, and G. Vassart. 1985. An unusually long poly (purine)-poly (pyrimidine) sequence is located upstream from the human thyroglobulin gene. Nucleic Acids Res. 13:5127-5144.

19. Desai, K. B., M. N. Metha, M. C. Patel, S. M. Sharma, L. Ramanna, and R. D. Ganatra. 1974. Familial goitre with absence of thyroglobulin and synthesis of thyroid hormones from thyroidal albumin. J. Endocrinol. 60:389-393.

20. Gerhing, W. J. 1987. Homeo boxes in the study of development. Science (Wash. DC). 236:1245-1252.

21. Mizuno, K., F. J. Gonzalez, and S. Kimura. 1991. Thyroid-specific enhancer-binding protein (T/EBP): cDNA cloning, functional characterization, and structural identity with thyroid transcription factor TTF-1. Mol. Cell. Biol. 11:4927-4933.

22. Krasnow, M. A., E. E. Saffman, K. Kornfled, and D. S. Hogness. 1989. Transcriptional activation and repression by Ultrabithorax proteins in cultured Drosophila cells. Cell. 57:1031-1043.

23. Ikuyama, S., H. Shimura, J. P. Hoeffler, and L. D. Kohn. 1992. Role of the cyclic adenosine 3 ', 5 '-monophosphate response element in efficient expression of the rat thyrotropin receptor promoter. Mol. Endocrinol. 6:1710-1715.

24. Shimura, H., S. Ikumaya, Y. Shimura, and L. D. Kohn. 1993. The cAMP response element in the rat thyrotropin receptor promoter: regulation by each decanucleotide of a flanking tandem repeat uses different, additive, and novel mechanisms. J. Biol. Chem. 258:24125-24137.

25. Reith, W., S. Satola, C. Herrero-Sanchez, I. Amaldi, B. Lisowska-Grospierre, C. Griscelli, M. R. Hadam, and B. Mach. 1988. Congenital immunodeficiency with a regulatory defect in MHC class II gene expression lacks a specific HLA-DR promoter binding protein RF-X. Cell. 53:897-906.

26. Tatsumi, K.-i., K. Miyai, T. Notomi, K. Kaibe, N. Amino, Y. Mizuno, and H. Kohno. 1992. Cretinism with combined hormone deficiency caused by a mutation in the Pit-1 gene. Nat. Genet. 1:56-58.

27. Radovick, S., M. Nations, Y. Du, L. A. Berg, B. W. Weintraub, and F. E. Wondisford. 1992. A mutation in the POU-homeodomain of Pit-1 responsible for combined pituitary hormone deficiency. Science (Wash. DC). 257:1115-1118.

28. Pfaffle, R. W., G. E. DiMattia, J. S. Parks, M. R. Brown, J. M. Wit, M Jansen, H. Van der Nat, J. L. Van den Brande, M. G. Rosenfeld, and H. A. Ingraham. 1992. Mutation of the POU-specific domain of Pit-1 and hypopituitarism without pituitary hypoplasia. Science (Wash. DC). 257:1118-1121. 